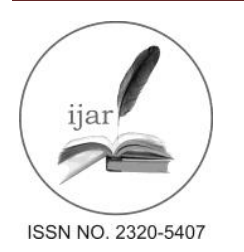

Journal homepage: http://www.journalijar.com
Journal DOI: 10.21474/IJAR01

RESEARCH ARTICLE

\title{
NYMPHOIDES BALAKRISHNANII SP. NOV. (MENYANTHACEAE), A NEW SPECIES FROM THE LATERITIC PLATEAU OF SOUTHERN WESTERN GHATS, INDIA.
}

\section{*Biju P. ${ }^{1,4}$, Josekutty E. J. ${ }^{2,4}$, Muhammed Haneef K. A ${ }^{3}$ and Jomy Augustine ${ }^{4}$.}

1. Department of Botany, Government College, Kasaragod, Vidyanagar P.O., Kasaragod - 671123, Kerala, India.

2. Department of Botany, Government Brennan College Thalassery, Dharmadam P.O., Kannur - 670106, Kerala, India.

3. Department of Applied Botany, Mangalore University, Konaje P.O., Mangalore - 574199, Karnataka, India.

4. Department of Botany, St. Thomas College, Pala, Arunapuram P.O, Pala - 686574, Kerala, India.

\begin{tabular}{|c|c|}
\hline Manuscript Info & Abstract \\
\hline n & \\
\hline Manuscript History: & A new species Nymphoides balakrishnanii, collected from seasonal pond in \\
\hline $\begin{array}{l}\text { Received: } 15 \text { May } 2016 \\
\text { Final Accepted: } 22 \text { June } 2016\end{array}$ & species is related to the Nymphoides parvifolia in the habit, tetramerous \\
\hline Published Online: July 2016 & $\begin{array}{l}\text { flowers and tuberculate seeds but differs in broad wings and long hairs on the } \\
\text { petals, oblique and introrse anthers, included stigma, bearded hypogynous }\end{array}$ \\
\hline & \\
\hline
\end{tabular}

kerala, Menyanthaceae, New

species, Nymphoides

balakrishnanii,.

*Corresponding Author

Biju P.

Copy Right, IJAR, 2016,. All rights reserved.

\section{Introduction:-}

Nymphoides Séguier. is the largest genus of the family Menyanthaceae with 40 species (Li et al. 2002) distributed in the tropical and temperate regions of the world. The genus is represented by eight species in India (Sivarajan et al.1993, Gupta et al. 2000). The Nymphoides resembles with Nymphaeaceae members in the floating leaves, but easily distinguished from the later using floral characters. In India, the genus Nymphoides Séguier. is represented by both dioecious species and bisexual species. The dioecious species are very rare, they are Nymphoides krishnakeasra Joseph \& Sivar. and Nymphoides macrospermum Vasudevan. The bisexual species are Nymphoides aurantiaca (Dalz.) Kuntze., Nymphoides hydrophylla (Lour.) kuntze., Nymphoides indica (L.) Kuntze., Nymphoides parvifolia Kuntze., Nymphoides sivarajanii Joseph. and Nymphoides peltata (S. G. Gmel.) Kuntze.

During the study of ponds in the lateritic hillocks Southern Western Ghats, India, the authors collected a different specimen of Nymphoides. Detailed study of the specimen showed its novelty. Hence this new specimen is described here as new species.

\section{Taxonomy:-}

Nymphoides balakrishnanii Biju, Josekutty, Haneef \& Augustine J. sp. nov. Type:-INDIA. Kerala: Kasaragod District, Koovapara lateritic plateau, N 1200'46.8", E 075³4'06", 190 m, 18 July 2014, Biju \& Jomy 2470 (Holotype CAL!, Isotype MH!). Figures $1 \& 2$. 


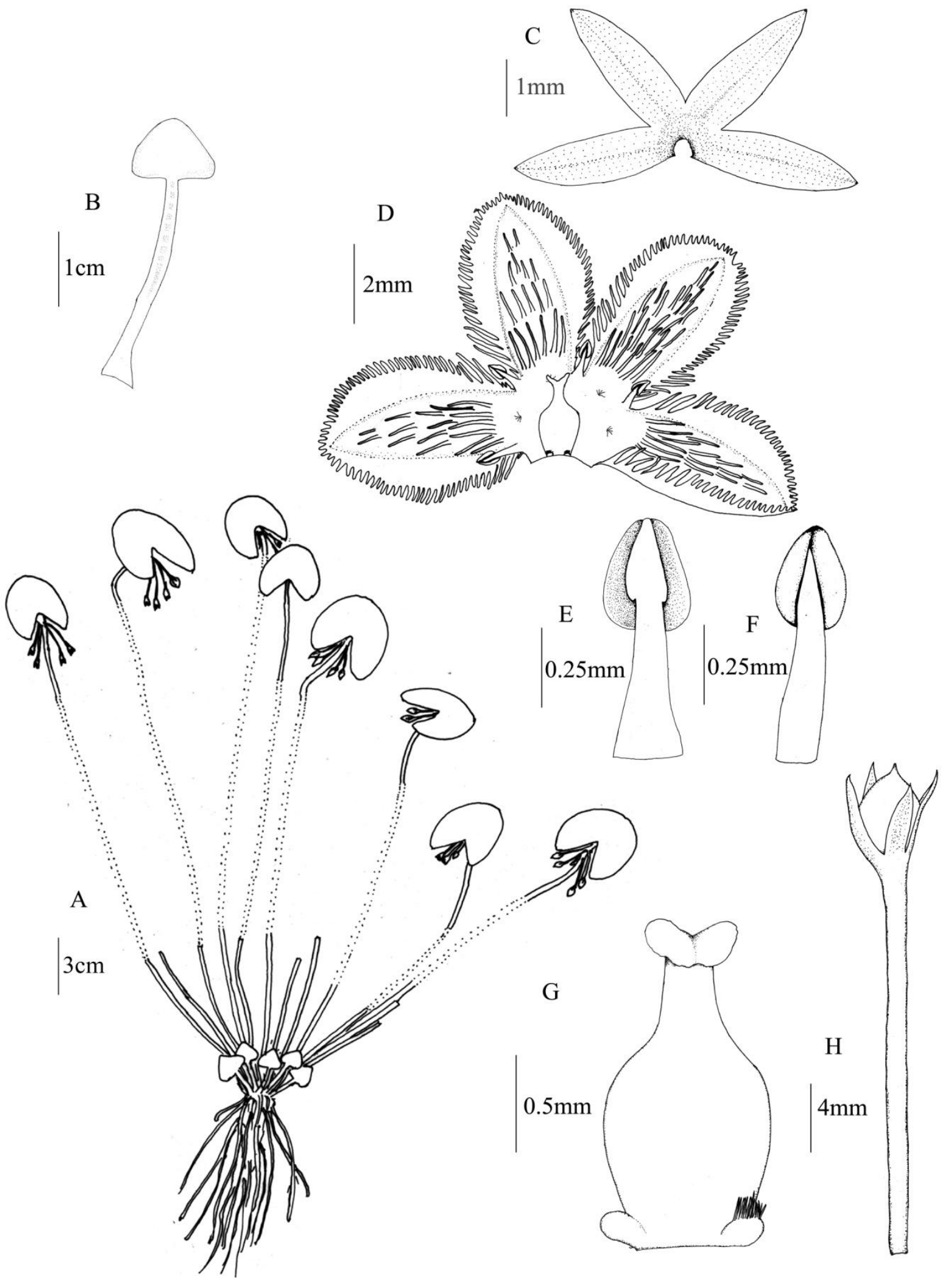

Figure 1:- Nymphoides balakrishnanii (A) Habit. (B) Basal leaf. (C) Calyx. (D) Corolla spread out. (E) Stamen ventral view. (F) Stamen dorsal view. (G) Carpel with hypogynous bearded gland. (H) Fruit. 

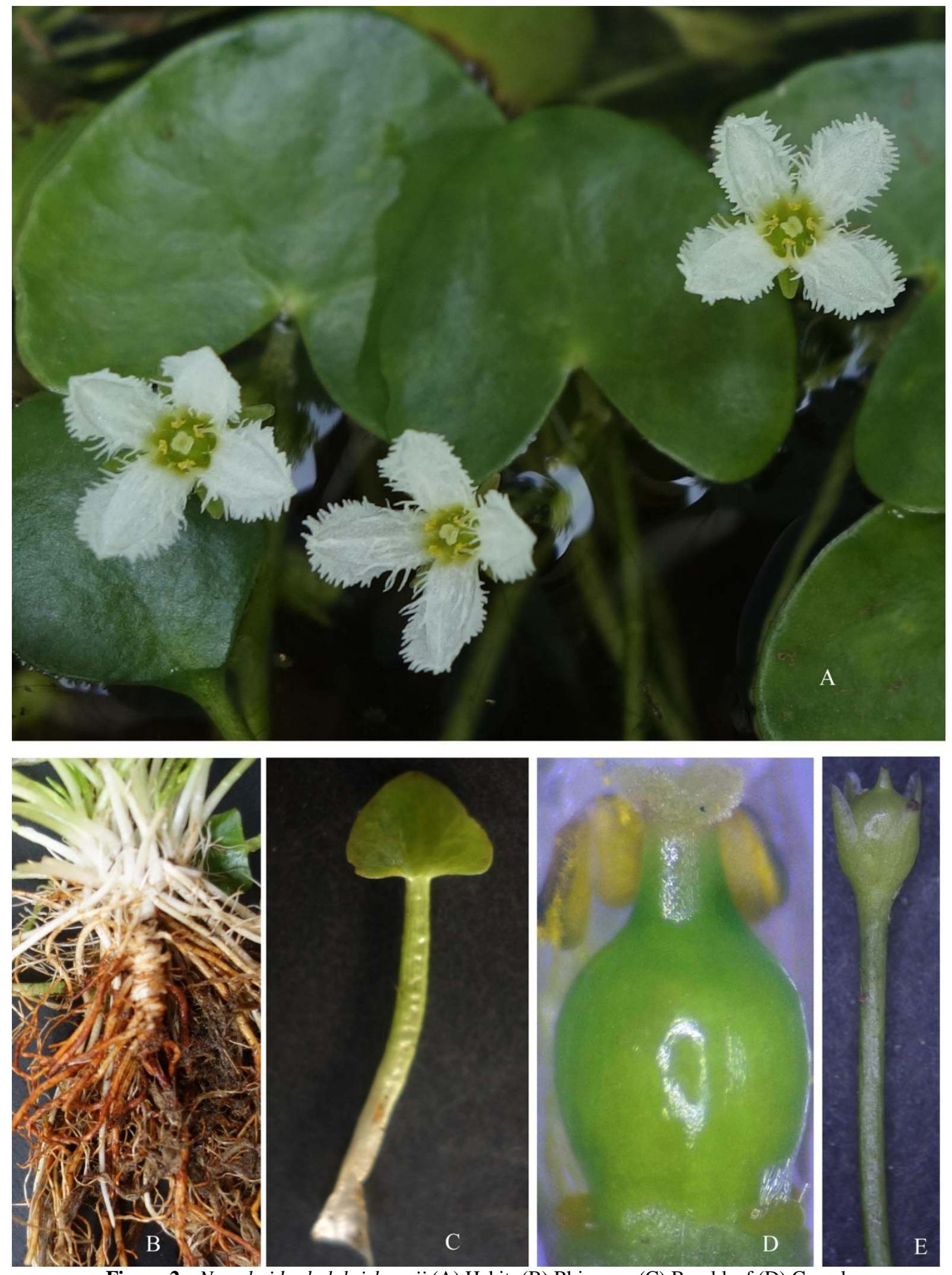

Figure 2:- Nymphoides balakrishnanii (A) Habit. (B) Rhizome. (C) Basal leaf (D) Carpel with hypogynous bearded gland. (E) Fruit. 
Freshwater rhizomatous annual; rhizome vertical, cylindrical, 2-2.4 $\times 0.4-0.7 \mathrm{~cm}$, densely covered by roots. Roots many, thick, spongy, unbranched or rarely branched. Leaves dimorphic; submerged sterile leaves in rosettes. Lamina deltate-ovate, $8-10 \times 7-8 \mathrm{~mm}$, glabrous, veins obscure, margins entire, acute-obtuse at apex, truncate at base; petiole spongy, 4-5 cm long, terete, sheathing at the base. Fertile branches many, arise from the axils of sterile leaves, 6-30 cm long, green, length variable with depth of the water, uniphyllous. Fertile leaves 4.5-5 × 4.4-4.8 cm; lamina orbicular-obovate, deeply cordate at base, margins distantly crenate, veins palmately reticulate; petioles short, up to 2-2.2 mm long, base dilated with two triangular membranous wings protecting the flower buds. Flowers in fascicles of 4-10 at the junction of petiole and branches, opening centripetally, bisexual, 9-12 mm across, tetramerous, pedicellate; pedicels 3-9 mm long, greenish, glabrous; bracts membranous triangular; calyx lobes 4, basally fused, linear-lanceolate, green, margins hyaline, 3-3.5 × 09-1.2 mm; corolla white, rotate, corolla tube 2-2.2 $\mathrm{mm}$ long, throat yellow, corolla lobes 4; lobes $4-5.5 \times 1.2-1.5 \mathrm{~mm}$, distinctly winged; wings $0.5-0.75 \mathrm{~mm}$, involute, margins with long whip like glandular hairs; hairs up to $1.4 \mathrm{~mm}$, papillate, corolla lobes dorsally covered by long multicellular glandular hairs, ventral side covered by short unicellular glandular hairs. Stamens 4 , arising from the sinus of the corolla lobes, epipetalous, introrse, oriented obliquely downwards so as to touch the stigma; filaments $0.5-0.6 \mathrm{~mm}$ long, hyaline, base broad; anther ovoid, bithecous, $0.3-0.4 \times 0.2-025 \mathrm{~mm}$, black along the dorsal side, yellow on the ventral side; connective broad, conical, projects above the anther lobes; pollen grains yellow; clusters of glandular hairs alternates with the stamens, 3-6 hairs in each cluster, hair up to $0.4 \mathrm{~mm}$ long. Carpels bottle shaped; ovary obovoid, green, glabrous, $1-1.2 \times 0.8-1 \mathrm{~mm}$, unilocular with parietal placentation; style terminal, 0.4-0.6 long; stigma bipartite, lobes flattened, semicircular, covered by glandular hairs, included, yellow. Fruit, oblong-obovoid, 4-5 × 2-2.5 mm, stalk $2.2 \mathrm{~cm}$, style persistent; fruiting calyx equal or exceeds the fruit. Seeds brownish black, 1-1.2 mm across, tuberculate; tubercles in clusters, faveolate.

\section{Diagnosis:-}

Nymphoides balakrishnanii is allied to Nymphoides parvifolia in the habit, tetramerous flowers and tuberculate seeds but differs in broad wings and long hairs on the petals, oblique and introrse anthers, included stigma, bearded hypogynous glands and larger fruiting calyx.

\section{Etymology:-}

The new species is named to honor Mr. V. C. Balakrishnan, a dedicated conservation biologist in Northern Kerala.

\section{Similar species:-}

The Nymphoides balakrishnanii is similar to Nymphoides parvifolia in the tetramerous flowers and tuberculate, but differs in many characters. Table 1.

Table 1:- Comparison of characters of Nymphoides parvifolia and Nymphoides balakrishnanii.

\begin{tabular}{|c|c|c|}
\hline Characters & Nymphoides parvifolia & Nymphoides balakrishnanii \\
\hline Rhizome & Obconical & Cylindrical \\
\hline Sterile leaves & Ovate-rhomboid & Deltate-ovate \\
\hline Fertile leaves & $\begin{array}{l}\text { Ovate-orbicular, } 4-4.5 \times 3-3.5 \mathrm{~cm} \text {, green with } \\
\text { pinkish tinge, petiole } 2-4 \mathrm{~mm} \text { long }\end{array}$ & $\begin{array}{l}\text { Obovate-orbicular, } 4.5-5 \times 4.4-4.8 \mathrm{~cm} \text {, green, } \\
\text { petiole } 2-2.2 \mathrm{~mm} \text { long. }\end{array}$ \\
\hline Flower & Small, 5-6 $\mathrm{mm}$ in diameter & Larger, $9-12 \mathrm{~mm}$ in diameter \\
\hline Calyx & Calyx lobes $2 \times 1 \mathrm{~mm}$, pinkish at the apex & Calyx lobes $5 \times 1 \mathrm{~mm}$, greenish at the apex \\
\hline Corolla & $\begin{array}{l}\text { Margins fimbriately toothed towards the apex, } \\
\text { wings absent, a ring of hairs present at the } \\
\text { throat, ventral side glabrous. }\end{array}$ & $\begin{array}{l}\text { Broadly winged with long papillate hairs } \\
\text { along the margin, long hairs present all along } \\
\text { dorsal side, Short glandular hairs present on } \\
\text { the lower side. }\end{array}$ \\
\hline Stamen & $\begin{array}{l}\text { Vertically oriented, filaments long, anther } \\
\text { cream-yellow }\end{array}$ & $\begin{array}{l}\text { Obliquely oriented, filaments short, anther } \\
\text { yellow-black }\end{array}$ \\
\hline Carpel & $\begin{array}{l}\text { Stigma projects above the corolla tube, } \\
\text { hypogynous glands not bearded }\end{array}$ & $\begin{array}{l}\text { Stigma included in the corolla tube, } \\
\text { hypogynous glands bearded. }\end{array}$ \\
\hline Capsule & Capsule project much beyond the fruiting calyx & $\begin{array}{l}\text { Capsule equal or slightly shorter than the } \\
\text { fruiting calyx. }\end{array}$ \\
\hline
\end{tabular}




\section{Distribution:-}

The new species is restricted to a seasonal pond in the lateritic hillocks of Koovapara, Kasaragod, Kerala, India.

\section{Conservation status:-}

The new species shows small populations in the seasonal pond at the type locality. The local people use the seasonal pond as a water source. The uncontrolled human interactions is a threat to the existence of this endemic species.

\section{Acknowledgments:-}

The authors are indebted to the Principal, St. Thomas College, Pala, Kerala for providing necessary laboratory facilities for the work. The first author is grateful to the Principal, Govt. College, Kasaragod, Kerala for providing necessary support for the work. The first and second authors are thankful to University Grants Commission for providing financial support as UGC-FIP.

\section{References:-}

1. Joseph, K. T. (1991): Nymphoides sivarajanii (Menyanthaceae), a New Species from India. Willdenowia, 20(2): 135-138.

2. Joseph, K. T. and Sivarajan, V. V. (1990): A new species of Nymphoides (Menyanthaceae) from India. Nordic journal of Botany 10(3):281-284.

3. Gupta, S., Mukherjee, A. and Mondal, M. (2000): A review of the Menyanthaceae Dumortier in India. Acta Botanica Hungarica 42: 119-137.

4. Sivarajan, V. V. and Joseph, K. T. (1993): The genus Nymphoides Séguier (Menyanthaceae) in India. Aquatic Botany. 45: 145-170.

5. Sivarajan, V. V., Chaw, shu-miaw. and Joseph, K. T. (1989): Seed coat micromorphology of Indian species of Nymphoides (Menyanthaceae). Bot. Bull. Academia Sinica. 30: 275-283.

6. Li, Sung-Po., Hsieh, Tsung-Hsin. and Lin, Chun-Chi. (2002): The Genus Nymphoides Séguier (Menyanthaceae) in Taiwan. Taiwania. 47(4): 246-258.

7. Schmidt-Mumm, Udo. (2005): Notes on the genus Nymphoides (Menyanthaceae) of Colombia. Caldasia. 27(1): $127-130$

8. Vasudevan, R. (1968): A new species of Nymphoides (Menyanthaceae) from South India. Kew Bulletin 22: 101-106. 